\title{
Xq27.3q28 duplication syndrome
}

INSERM

\section{Source}

INSERM. (1999). Orphanet: an online rare disease and orphan drug data base. $\underline{\text { Xq27.3q28 }}$ duplication syndrome. ORPHA:261483

Xq27.3q28 duplication syndrome is a recently described syndrome characterized by short stature, hypogonadism, developmental delay and facial dysmorphism. 